\title{
Distinguishing Racism, Not Race, as a Risk Factor for Child Welfare Involvement: Reclaiming the Familial and Cultural Strengths in the Lived Experiences of Child Welfare-Affected Parents of Color
}

\author{
Tricia N. Stephens
}

check for updates

Citation: Stephens, Tricia N. 2021. Distinguishing Racism, Not Race, as a Risk Factor for Child Welfare Involvement: Reclaiming the Familial and Cultural Strengths in the Lived Experiences of Child

Welfare-Affected Parents of Color. Genealogy 5: 11. https://doi.org/ 10.3390/genealogy5010011

Received: 12 October 2020

Accepted: 12 January 2021

Published: 26 January 2021

Publisher's Note: MDPI stays neutral with regard to jurisdictional claims in published maps and institutional affiliations.

Copyright: (c) 2021 by the author Licensee MDPI, Basel, Switzerland. This article is an open access article distributed under the terms and conditions of the Creative Commons Attribution (CC BY) license (https:// creativecommons.org/licenses/by/ $4.0 /)$.
Silberman School of Social Work, City University of New York-Hunter College, New York, NY 10035, USA; ts42@hunter.cuny.edu

\begin{abstract}
Child welfare-affected parents of color (CW-PaoC) are often described using language that is deficit-focused, their families depicted as fragile and living in a near constant state of crisis and need. This commentary challenges the stereotypes created by hyper-attention to these parents struggles and situates them, and their families, within the broader context of the American appetite for family separation, wherein specific types of families are targeted for scrutiny, intervention and regulation. The concept of fragility within families is dissected to illustrate the ways in which racism and classism demarcate certain families for separation. Excerpts from two separate interviews conducted with Black mothers in 2014 and 2020 are used to illustrate how the appetite for family separation is currently fed. Familial and cultural strengths that counteract the prevailing deficitfocused narrative of CW-PaoC, particularly Black parents, are discussed. This commentary ends with a call for the dissolution of the CW system in its current regulatory form and the rebuilding of family-centered supports that center familial strengths.
\end{abstract}

Keywords: child welfare; race; racism; child welfare-affected parents of color; familial wealth and strength

\section{Introduction}

Time suspended, his pleas for his life amplified by the crowd-the seconds counting upward on the video screen. As the last breaths passed his lips, his cries for his mother racing to the heavens the nation erupted in fury. The racial reckoning movement of 2020, ignited by the public murder of George Floyd and other unarmed Black people by uniformed, on-duty police officers, spotlighted America's systemic racism in ways hard to ignore (Taylor 2020). In the eight minutes and forty-six seconds (8:46) that the police officer knelt on Mr. Floyd's neck, America's carefully cultivated legacy of racial violence was captured, frame by awful frame. Assured of his place and protections in American society, the White officer stared remorselessly into the camera lens, offering America an unfiltered view into a world known intimately to many Black Americans. This is a world of violence at the hands of and decisions made by people and institutions sworn to protect them, which instead stifle the breath and potential from their lives. The impunity with which that officer took Mr. Floyd's life, apparently believing there would be no consequence for the baseless violence he perpetrated, is a hallmark of systemic racism.

This commentary is a call to action to acknowledge and disrupt the systemic racism that operates with similar impunity in the American child welfare $(\mathrm{CW})$ system. First, the concept of race as a "risk factor" for CW involvement, is explored. Second, the uniquely American appetite for family separation as a preferred method of dealing with familial problems is detailed. The role played by antipoverty and racist sentiments in feeding this appetite for separation is discussed. Third, the utility of the image of the "fragile family" is interrogated for its use in keeping certain families CW-involved. Fourth, the familial 
and cultural strengths of child welfare-affected parents of color (CW-PaoC) are presented using summaries from interviews conducted with two separate child welfare-affected Black mothers in 2014 and 2020. Finally, implications for policies and practices that unearth and uproot systemic racism in CW are detailed.

\section{Race as a Risk Factor for Child Welfare Involvement}

Race is a spurious concept-it was fabricated and socially agreed upon to allow White, land-owning men to consolidate wealth and power within a select group of people (Wilkerson Isabel 2020). Though manufactured, race continues to be used as a variable in health and social science research, and has been repeatedly found to be significantly correlated with poor functional outcomes (Kawachi et al. 2005; National Center for Health Statistics U.S. 2016). Race has been heavily researched, but measurements that discretely capture the effects of racially-based violence on racial minority groups are sparse (Brave Heart and DeBruyn 1998). This avoidance of explicit, scientific interrogation of the effects of White hegemony/supremacy (Pon 2009) is another marker of systemic racism. It refuses to name racial violence and makes invisible the pain of those who endure it, while repeating references to the correlations between a dubious variable and poor functional outcomes. The message broadcasted loudly, and backed by scientific inquiry, is that the skin a person is born in and the racialized group to which they belong is inherently risky, inherently bad. Race is a powerful divider in America, where undeserved privileges are doled out to some, while others are marked as undeserving and subject to subhuman treatment.

The CW system emerged and exists within the systemic racism that permeates the rest of American society, and CW-PaoC (CW-PaoC and parents are used interchangeably going forward) enjoy few protections within that racialized social stratification (Mays et al. 2007). Native and African Americans, two groups with a shared history of fighting against racial violence and historical traumas, remain grossly over-represented in the American CW system in comparison to their representation in the general population (Davidson et al. 2019; USDHHS 2019; Vidal Sarah et al. 2017). In an analysis of the rates of foster care placement between 2000 and 2011, Wildeman and Emanuel (2014) found that 11.5\% of AfricanAmerican children and $15.4 \%$ of Native American children were likely to enter the foster care system between ages zero and eighteen. Latinx families, specifically those who are phenotypically aligned with people of color and who live in poverty, have also found themselves subject to heavy CW involvement and regulation. 5.4\% of all Latinx children were found to be likely to enter foster care in Wildeman and Emanuel's study, while 4.9\% of White and $2.1 \%$ of Asian children entered foster care during that time period. While the combined effects of race and poverty leave families exposed to CW involvement, Courtney Mark et al. (1996) and Dettlaff et al. (2011) found that race, specifically being Black, significantly increases the likelihood of CW involvement from referral through substantiation. Race, though not based in real differences between people, increases the likelihood of a family becoming and remaining CW-involved in America.

\section{A Uniquely American Appetite for Family Separation}

Separation of specific types of families is a culturally accepted practice in the US. Though family values are touted as American values, all families are not respected equally. Some families are susceptible to the separation that directly results from the vagaries of larger political agendas or social zeitgeists (Golash-Boza and Hondagneu-Sotelo 2013). This country's appetite for family separation can be traced from the forced removal and violent assimilation through boarding school attendance of children from First Nations Tribes (Adams 1995), the sale at auction blocks of Africans and their children who were enslaved (Dunaway 2003) and the removal of the children of poor White immigrants sent from New York City on orphan trains to the American West (Trammell 2009). Americans were revolted by the contemporary televised images of traumatized Latinx children who were separated from their parents at the Southern border under the country's Zero Tolerance Policy (Linton et al. 2017). Sickened by the images of Brown children living in conditions 
reminiscent of concentration camps, the argument was made that this would not be tolerated if those children were White and middle class (de la Peña Cristina Muñiz and Punsky 2019). Yet, there is societal tolerance of child removals every day at near pandemic levels in communities of color and poor communities across the country. These removals are not televised. The cameras show up and headlines blare whenever a child is killed (Newman 2008), further perpetuating the stereotype of all CW-PaoC as dangerous. Yet year after year, the USDHHS's Adoption and Foster Care Analysis and Reporting System (AFCARS) tells the story of poor families and families of color comprising the vast majority of families in the CW system, with Black and Native families disproportionately represented (USDHHS 2019).

\section{Racism as the Risk Factor in Child Welfare}

Race may be spurious but racism is very real. Remarkably, while race has been singled out as a "risk factor" for CW involvement, racism has not. Racism systematically drives people of color into some of the harshest living conditions in the US (Devakumar et al. 2020), but is not measured or designated as a "risk factor" for CW involvement. Many CW-PaoC live in conditions of chronic and compounded exposure to the deleterious effects of racism, complex trauma and extreme stress (Stephens 2015, 2018, in press). Yet racism is not explicitly identified as the cause of these harsh living conditions. Instead, many parents are blamed for the difficulties they encounter as they try to live and raise their children with limited means and restricted access to opportunities to improve their circumstances. Parents with the least access to resources and privilege are held to standards of perfection when they engage with CW. Ironically, these parents, who know what it is to be poor and locked out of opportunity, are measured by the hegemonic norms of those who are most protected. Their fortitude and perseverance are erased when their efforts to support their families on limited means are erased by the term "neglect". Parents are labelled as resistant, non-compliant, safety risks and angry. Their behaviors thoroughly researched, with the findings used to justify the heavy financial, personal and societal cost of their surveillance and control (Roberts 2009). Though costly (USDHHS 2020), the intergenerational cycling of some of these families through the CW system has failed to raise alarms about the lack of effectiveness and inherent injustice of this entire approach.

\section{Parents' Accounts of Their Experiences in the Child Welfare System}

Treating CW-PaoC as adversaries instead of as allies is wasteful and ineffective. The financial cost to society of current CW practices is great, but the cost to families is immeasurable. I interviewed Rashida (pseudonym) in 2014. Rashida was raised in a middle-class home in Queens. She lost both of her parents at an early age and as a teen moved in with a boyfriend who sold drugs. He became her first dealer and when they broke up, her struggles with substance use continued. Over the years that she struggled to overcome her addiction, Rashida lost all of her children to foster care. Some of her children were taken in by her siblings who never denied her access to visiting them when she could. Those children were never told that their mother was a bad person, they were told that she could not take care of them. Some of her other children were adopted by people unknown to her after her parental rights were terminated.

When Rashida became pregnant with her last child, she was determined to be a mother to him. She recounted the fight she had with workers who, based on her history, had already decided that she could not raise this child. She and her husband were homeless together but still managed to complete every mandated anger management class, parenting class and service requirement that was presented to them. Rashida described building a relationship with a worker who believed that she could be a parent. Together, they worked to get her housing which was the turning point for her and her husband's ability to provide stability for their family.

It was in that same apartment that I sat and conducted the interview thirteen years after her reunification with her two youngest children. I met them that day along with 
one of her older sons who had since moved in with her. She had reunited with all of her children and now a grandmother, the children Rashida was not entrusted to raise brought their children to her for care so they could go to work or run errands. Rashida is an integral part of her family unit. Years after innumerable dollars were spent on their separation, they found their way back to each other. Rashida's family is not perfect, no family is. Families like hers deserve a chance to work through their struggles without the threat of separation.

Nowhere is this cost to families and society more disturbing than with young CW$\mathrm{PaoC}$ raised in the CW system, who then lose their children to the very system that raised them. These parents have experienced first-hand the transformation of the system from one ostensibly meant to protect and support them, into one where they became pariahs. I interviewed Belle (pseudonym) in early 2020. Belle was removed from her mother at eight years old and remained in foster and group homes until she aged out of the system as an adult. She was in her late teens when she gave birth to her first child, a son. He was removed from her when she sought medical care for him, terrified when he could not keep any food down. Belle was involved in CW and Family Court as a parent and child simultaneously. When she went to court in the case against her mother, she described having a place to sit, being told what time she needed to get to the court for the hearing and being provided with information about her case. Her experience as a child in CW had not prepared her for the realities of how parents, possibly including her own mother, were treated. When she went to her court hearing as a parent, Belle described waiting in an overcrowded waiting area in the courthouse along with other Black and Brown mothers. She was given no information about her son. Her son was returned to her care without apology or explanation after a month in foster care. The hospital confirmed that he had an obstruction and provided him with the medical care she had voluntarily sought out for him. Belle quickly went from being viewed as a deserving victim to an undeserving villain and her battles with CW would continue for five years (and include her second child after she was born a few years later). She eventually reunified with both of her children but was still shaken at the time of the interview.

\section{Cultural Wealth and Strength of CW-PaoC}

Parents like Rashida and Belle need help -a fact that is freely acknowledged by many $\mathrm{CW}-\mathrm{PaoC}$. It is the way in which the CW system offers help that most find unpalatable. CW-PaoC interface with a CW system that is ill-equipped or refuses to acknowledge their strengths because those strengths do not reflect hegemonic standards. How could these strengths look the same? Many CW-PaoC, particularly Black parents, must become adept at survival against intense racial trauma which can target them personally, their children and extended families without warning and across social and occupational settings. There is no measure used to capture these strength that many parents excel at. CW-PaoC know that they live within a society that will:

a. Prioritize the incarceration of their family members over investing in their education and/or mental health.

b. Pity their poverty even after they have worked full-time at one or more jobs instead of fighting for a living wage within the world's most economically advantaged country.

c. Extract their wage work without the basic acknowledgement of their human need for and right to paid sick leave, health insurance and paid time off.

d. Remove their children from their care for their struggles with poverty, mental health or substance abuse, often using the label of neglect. Once removed, the state and federal government will finance alternate housing and care for their children, but will not provide direct financial support to parents. Many CW-PaoC are mystified by the availability of funds invested in separating them from their children that seem to disappear when they ask for financial help.

$\mathrm{CW}-\mathrm{PaoC}$ are neither naïve nor fragile. They have lives and live within communities that contain great strength and wealth as well as struggles (Yosso Tara 2005). Yosso asks the important question of whose culture has wealth? The high unemployment rate among 
African Americans is often highlighted for the stressors associated with living in poverty (United States Department of Labor Statistics 2019). These statistics, however, do not show the cultural strength that emerged in Black communities in the face of racist exclusion from economic opportunity. High unemployment within Black communities in America has spurred a tremendous entrepreneurial spirit within the community. Black people have found ways to make money that do not require being hired by others. From becoming street vendors to barbers and hairdressers, the women who sew and braid hair, the young women who work shea butter into all forms of hair and skin products, Black people have learned how to make money outside of systems that WILL NOT employ them.

Perhaps the most notable of these entrepreneurial efforts are the street hustlers who contributed to their family incomes in lean times with money made from selling small amounts of marijuana. Many of those men remain incarcerated (Geller and Fagan 2010), while states and the federal government debate how to tax a drug (Henchman 2016) that long supplemented Black households outside of the law. After refusing to employ Black men, America paid to incarcerate those who turned to selling a drug that many states have now legalized. The public outcry over the stark racial difference in who is now able to profit from the legalization of marijuana and who continues to be punished, has been heartening. However, we cannot forget that many of these incarcerated men are fathers to the CW-involved children we hold so much empathy for.

\section{Conclusions}

A CW system which intensively involves itself in families across generations, using separation as a primary tool of intervention, can no longer claim to be helping those families. Such a system, which has earned the mistrust of most families it has encountered, cannot be reformed into being supportive of families. It must be deconstructed and the harm inflicted on families acknowledged and remedied. Family separation should be rare, directed and effective, not protracted and multigenerational. The recent Covid-19 pandemic forced some $\mathrm{CW}$ agencies to be creative and proactive in how they work with families. As removals continued, some agencies facilitated speedy reunifications so that children and their families did not need to be separated during a pandemic. These rapid reunifications should be studied for how they were achieved, the reduction of bureaucratic delays made a priority even after the pandemic has passed. Agencies have used technology to increase the level of contact between parents and children so that parents can be consistent in their children's lives, greeting them the first thing in the morning and putting them to bed at night. In order to be equitable, many agencies secured funds to provide CW-PaoC the devices and data plans needed to stay in touch as Covid decimated communities of color living in poverty. The decline in reports of child maltreatment without a sharp increase in child fatalities during the early months of the pandemic should prompt an overhaul of the entire CW reporting system, as the majority of reports made even before Covid are highly disruptive to families but are unsubstantiated (Stephens forthcoming; USDHHS 2019).

If the CW system does not grapple with the systemic racism built into its routine operation, it will continue to exist as just another problem that CW-PaoC who are already struggling need to deal with. When racism, classism and the American appetite for separation collide, the stage is set for a system that consumes parents in unending services that do not meet their families' needs. It is time for the CW system to meet parents as equals and recognize their strengths and knowledge about living and caring for their families in the realities of an American society at the beginning of its reckoning with effects of racism.

Funding: This research received no external funding.

Institutional Review Board Statement: Not applicable.

Informed Consent Statement: Not applicable. 
Data Availability Statement: No new data were created or analyzed in this study. Data sharing is not applicable to this article.

Conflicts of Interest: The author declares no conflict of interest.

\section{References}

Adams, David Wallace. 1995. Education for Extinction: American Indians and the Boarding School (Experience 1875) Experience, 1875-1928. Lawrence: University Press of Kansas.

Brave Heart, Maria Yellow Horse, and Lemyra M. DeBruyn. 1998. The American Indian holocaust: Healing historical unresolved grief. American Indian and Alaska Native Mental Health Research 8: 60-82.

Courtney Mark, Richard P. Barth, Jill Duerr Berrick, Devon Brooks, Barbara Needell, and Linda Park. 1996. Race and child welfare services: Past research and future directions. Child Welfare New York 75: 99-138.

Davidson, Ryan D, Claire S. Tomlinson, Connie J. Beck, and Anne M. Bowen. 2019. The revolving door of families in the child welfare system: Risk and protective factors associated with families returning. Children and Youth Services Review 100: 468-79. [CrossRef]

de la Peña Cristina Muñiz, Lisa Pineda, and Brenda Punsky. 2019. Working with parents and children sseparated at the border: Examining the impact of the zero tolerance policy and beyond. Journal of Child Adolescent Trauma 12: 153-64. [CrossRef] [PubMed]

Dettlaff, Alan J., Stephanie L. Rivaux, Donald Baumann, John Fluke, Joan Rycraft, and Joyce James. 2011. Disentangling substantiation: The influence of race, income, and risk on the substantiation decision in child welfare. Children and Youth Services Review 33: 1630-37. [CrossRef]

Devakumar, Delan, Sujitha Selvarajah, Geordan Shannon, Kui Muraya, Sarah Lasoye, Susanna Corona, Yin Paradies, Ibrahim Abubakar, and E. Tendayi Achiume. 2020. Racism, the public health crisis we can no longer ignore. Lancet 395: e112-e13. [CrossRef]

Dunaway, Wilma. 2003. The African-American Family in Slavery and Emancipation. Cambridge: Cambridge University Press. Available online: https://content.schweitzer-online.de/static/catalog_manager/live/media_files/representation/zd_std_orig_zd_schw_ orig/002/352/492/9780521812764_table_of_content_pdf_1.pdf (accessed on 11 October 2020).

Geller, Amanda, and Jeffrey Fagan. 2010. Pot as pretext: Marijuana, race, and the new disorder in New York City street policing. Journal of Empirical Legal Studies 7: 591-633. [CrossRef]

Golash-Boza, Tanya, and Pierrette Hondagneu-Sotelo. 2013. Latino immigrant men and the deportation crisis: A gendered racial removal program. Latino Studies 11: 271-92.

Henchman, Joseph. 2016. Marijuana legalization and taxes: The impact of Section 280E. No. 232. Washington, DC: Tax Foundation Special Report.

Kawachi, Ichiro, Daniels Norman, and Dean E Robinson. 2005. Health disparities by race and class: Why both matter. Health Affairs 24: 343-52. [CrossRef] [PubMed]

Linton, Julie M., Griffin Marsha, and Alan J. Shapiro. 2017. Detention of immigrant children. Pediatrics 139: e20170483. [CrossRef] [PubMed]

Mays, Vickie M, Susan D Cochran, and Namdi W Barnes. 2007. Race, race-based discrimination, and health outcomes among African Americans. Annual Review of Psychology 58: 201-25. [CrossRef]

National Center for Health Statistics U.S. 2016. Health, United States, 2015: With Special (Feature on Racial and Ethnic Health Disparities. Available online: https:/ / www.ncbi.nlm.nih.gov/books/NBK367645/ (accessed on 10 October 2020).

Newman, Andy. 2008. Jury selection begins in murder trial of 7-year-old Brooklyn girl's mother. New York Times, September 16.

Pon, Gordon. 2009. Cultural competency as new racism: An ontology of forgetting. Journal of Progressive Human Services 20: 59-71. [CrossRef]

Roberts, Dorothy. 2009. Shattered Bonds: The Color of Child Welfare. New York: Civitas Books.

Stephens, Tricia. 2015. Traumatic Experiences and Perceptions of Parenting-A Mixed-Methods (Study of Poor Black and Latino Mothers with Single and Multigenerational Child Welfare Involvement. Ph.D. thesis, New York University, New York, NY, USA.

Stephens, Tricia. 2018. Recognizing complex trauma in child welfare-affected mothers of colour. Child and Family Social Work 24: 42-49. [CrossRef]

Stephens, Tricia. forthcoming. Black Parents Love Their Children Too: Addressing Anti-Black Racism in the American Child Welfare System. Social Work. in press.

Taylor, Keeanga-Yamahtta. 2020. Of course there are protests. The state is failing Black people. New York Times, May 29.

Trammell, Rebecca S. 2009. Orphan train myths and legal reality. The Modern American 2: 3-13.

United States Department of Labor Statistics. 2019. Labor Force Statistics from the Current Population Survey. Available online: https:/ / www.bls.gov/web/empsit/cpsee_e16.htm (accessed on 12 October 2020).

United States Department of Health and Human Services (USDHHS). 2019. Available online: https://www.acf.hhs.gov/cb/researchdata-technology/reporting-systems/afcars (accessed on 10 October 2020).

United States Department of Health and Human Services (USDHHS). 2020. Children's Bureau. Report to Congress on State Child Welfare Expenditures. Available online: https://www.acf.hhs.gov/sites/default/files/cb/cfs101_report_congress_2019.pdf (accessed on 10 October 2020).

Vidal Sarah, Dana Prince, Christian M Connell, Colleen M Caron, Joy S Kaufman, and Jacob K Tebes. 2017. Maltreatment, family environment, and social risk factors: Determinants of the child welfare to juvenile justice transition among maltreated children and adolescents. Child Abuse Neglect 63: 7-18. 
Wildeman, Christopher, and Natalia Emanuel. 2014. Cumulative risks of foster care placement by age 18 for US children, $2000-2011$. PLOS ONE 9: e92785.

Wilkerson Isabel. 2020. Caste: The Origins of Our Discontents. New York: Random House.

Yosso Tara, J. 2005. Whose culture has capital? A critical race theory discussion of community cultural wealth. Race, Ethnicity and Education 8: 69-91. [CrossRef] 